\title{
The Law of Nations at the Naval Academy in Copenhagen around 180o: the Lectures of Christian Krohg
}

\author{
Thor Inge Rørvik
}

Recent scholarship has no doubt contributed to a better understanding of the law of nature and nations by no longer regarding it exclusively as a topic developed in a limited number of classical works forming a single identifiable tradition, and, further, by identifying it as a subject of academic teaching established in the late seventeenth century and ending well into the nineteenth. As a consequence, the law of nature and nations should not only be measured by its theoretical coherence or originality, but also be understood by the way it was received, appropriated and transmitted in various institutional, legal and political contexts. Moving forward from this angle, it is, however, important to realize that we still know comparatively little about the workings of this tradition of moral and legal thinking and that we - in order to gain a better understanding of the matter - will need a more comprehensive mapping of the territory. The scope of this chapter is to contribute to such a mapping, by introducing a Danish-Norwegian textbook that has remained virtually unknown until today. The book in question is Forsøg til en Ledetraad ved Forelesninger over Folke-Retten (An Attempted Guide to Lectures on the Law of Nations), published in Copenhagen in 1803; its author is Christian Krohg (1777-1828) and the lectures on which the textbook is based were held at the Royal Danish Naval Academy in 1801 and 1802.

To introduce a textbook is, in many ways, a different enterprise from presenting an innovative theoretical work where one can highlight its contribution to an ongoing debate or focus on the way it makes established ways of thinking obsolete. A textbook will always remain anchored in a tradition that must be accounted for in order to understand its content. Before turning its attention to Krohg's lectures, this chapter will therefore begin with an attempt to sketch a contextual background against which they must be understood. Two contexts are particularly important here: 1) the way the law of nations was treated as an academic subject at the University of Copenhagen; and 2) the 
emergence of a different understanding of the subject in the 179os that put its mark on a generation of Danish-Norwegian jurists.

Three years after entering the University of Copenhagen as a student, Christian Krohg passed the final degree examination in the faculty of law in 1797 . He belonged to a circle of talented jurists who in the years to come would find themselves in important positions, both within and outside of the academic world. Inspired by their teacher, Professor Johan Friedrich Wilhelm Schlegel (1765-1836), the circle held the Kantian philosophy of law in high esteem, both as a key to the relation between moral philosophy and law and as a foundation upon which a scientific legal edifice should build. But despite his veneration of Kant, Schlegel had in his textbook on natural law refuted the idea of a distinct Weltbürgerrecht (cosmopolitan law), because this topic should be treated as a part of public law or the law of nations. ${ }^{1}$ That Schlegel was too much of a jurist to fall prey to what he believed to be philosophical chimeras is also evident in the way he outlines in his textbook the principles of the natural law of nations before moving on to what he referred to as the positive law of nations. This sub-discipline did not quite fit into his larger system, but he had included it because it was an important issue and no presentation of it was yet available to a Danish-Norwegian audience. Schlegel hoped that this amendment to what had hitherto been considered a sufficient outline of the law of nations would be appreciated, even if it involved a different way of looking at things and put new demands on the way a textbook should be written.

As a historical science the positive law of nations relies on facts. It is therefore necessary to provide the reader with references to where further information can be found concerning the different topics in question, whereas this is not necessary in the other parts of the book which deal with the exposition of truths of reason. ${ }^{2}$

If one looks at his predecessors' lectures, Schlegel was no doubt right to regard the positive law of nations as a neglected topic. And the reason was obvious.

1 J.W.F. Schlegel, Naturrettens eller den almindelige Retslares Grundscetninger (Copenhagen: Johan Frederik Schulz, 1798), I, 20 and II, 321.

2 Ibid., II, preamble (not paginated). Translations from Danish original works here and below are by the present author. 
The university statutes of 1732 and the regulations of the formal examination for a degree in law, introduced in 1736 , stated that students aspiring to the higher level of the grading scale (laudabilis or haud illaudabillis) should account for the principles of the law of nature and nations. The textbooks in use were, however, more or less Pufendorfian, and according to Pufendorf the law of nations 'is nothing other than the law of nature, insofar as different nations, not united with another by a supreme sovereignty, observe it, who must render one another the same duties in their fashion, as are prescribed for individuals by the law of nature.' ${ }^{3}$ Regarding the law of nature as the guiding principle also in matters of interstate relations, Pufendorf found it unnecessary to conduct a special treatment of the law of nations, because what he had already said about the law of nature and the duties of individuals could be applied either to whole states or to nations, which he considered to be moral persons. In the textbooks used at the University of Copenhagen until the middle of the eighteenth century, the law of nations was therefore treated only briefly, in connection with war and peace, alliances (treaties), and the holiness of envoys. ${ }^{4}$

The first attempt to give a comprehensive introduction to the law of nations and point out its place in the theoretical edifice of the law of nature came in a Wolffian textbook in 1776. According to its author, Professor Lauritz Nørregaard $\left(1745^{-1804)}\right.$, the law of nations was a part of jus naturae sociale - i.e. the natural law which deduces the rights and duties characterizing different social organizations. Because these organizations are either small (the household) or big (the state), jus naturae sociale must be divided into 1) jus naturae oeconomicum sive familiarum and 2) jus naturae politicum sive jus universale civitatum. The duties and rights imposed upon a state are either such that they concern only the state itself or they signify its rights and duties towards other states. In the first case they are a part of jus naturae politicum sic dictum; in the second they belong to jus gentium. ${ }^{5}$

3 Samuel Pufendorf, Elementorum Iurisprudentiae Universalis Libri Duo (166o), book I, chap. XIII, § 24. Here quoted from the English translation by W.A. Oldfather: Two Books of the Elements of Universal Jurisprudence, ed. Thomas Behme (Indianapolis, IN: Liberty Fund, 2009), 225. See also De jure naturae et gentium (1672), book II, chap. III, § 23.

4 The textbooks were Ludvig Holberg, Introduction til Naturens- og Folke-Rettens Kundskab (Copenhagen: Johan Kruse, 1716) and a Danish translation of De officiis hominis et civis made in 1735. See Knud Haakonssen, 'Holberg's Law of Nature and Nations,' in Ludvig Holberg (1684-1754). Learning and Literature in the Nordic Enlightenment, ed. Knud Haakonssen and Sebastian Olden-Jørgensen (London and New York: Routledge, 2017), 59-79.

5 Lauritz Nørregaard, Natur-Rettens første Grunde, 2nd ed. (Copenhagen: Gyldendals Forlag, 1784), §§ 164-167. 
Presented as a part of the system of natural law, the law of nations continued to be assessed with regard to the system's founding certainties. Throughout the eighteenth century, Danish-Norwegian jurists understood this system as a framework that could not itself be captured in legal terms and as a tacit philosophical foundation of contemporary legislation. In a more practical sense it was also considered to be a supplementary legal system. According to Nørregaard, natural law 'was the only subsidiary law that one can and should follow', and Schegel later stated that 'all positive laws should be founded on natural law, and where these are either silent or ambiguous, the jurists must take recourse to natural law as a jus subsidiarum.6 According to the university statutes of 1732 , the professor responsible for lecturing on Danish-Norwegian law had to demonstrate how this law 'complied with the law of nature and nations'. The purpose of this demonstration was to show that the absolutist state's legislation was in accordance with moral maxims and hence an expression of the dictates of reason. In the absence of an international legal system, the law of nations could not serve as a benchmark in the same sense as other parts of natural law. What it could do was provide general guidelines for wise statecraft and the handling of international relations. But the way the law of nations was taught at the University of Copenhagen until the late 179os simply ruled out the idea that it could be anything more than a part of a larger system. The idea of a discipline that took current international arrangements as its vantage point and also realized that binding agreements could modify the general maxims of natural law was never presented to the students. The professors on their part could hardly have been unfamiliar with this idea, because it was put forth in the works of Hugo Grotius and Emer de Vattel.

In the prolegomena to his great work, Grotius declared that as the laws of each state respected the benefits of the state, 'so amongst all or most States there might be, and in Fact there are, some Laws agreed on by common Consent, which respect the Advantage not of one Body in particular, but of all in general. And this is what is called the Law of Nations. ${ }^{7}$ The difference between natural law and the law of nations amounted to more than the fact that the first was a just inference from the principles of nature whereas the second originated in a universal consent, because 'that which cannot be deduced from certain Principles by just Consequences, and yet appears to be everywhere observed, must owe its rise to a free and arbitrary Will!: ${ }^{8}$ Grotius here identified

6 Ibid., § 158; see also Schlegel, Naturrettens, § 15 .

7 Hugo Grotius, De jure belli ac pacis (1652), Prolegomena, 18, 41. Here quoted after the English translation from the edition of Jean Barbeyrac, ed. by Richard Tuck: The Rights of War and Peace (Indianapolis, IN: Liberty Fund, 2005), 96.

8 Ibid., 112. 
the law of nations as an existing body of law that, on the one hand, differed from jus naturae by being a result of the human will, and, on the other hand, differed from civil law by not being enforceable by a court. By regarding the law of nations as more flexible or adaptable to local conditions than the universal timeless principles of natural right, Grotius had thus admitted state interests into the picture. ${ }^{9}$ Although Vattel wrote his major work under different historical conditions and with other problems in mind, there is a similarity between the Grotian understanding of jus gentium and Vattel's distinction between the necessary law of nations and the positive law of nations, consisting of a voluntary, conventional and customary law. What distinguished the positive law from the necessary was the fact that the three kinds of law of which it consisted 'proceed from the will of nations, - the voluntary from their presumed consent, the conventional from an express consent, and the customary from tacit consent'.10 What characterized the voluntary law was that, despite being a part of the positive law of nations, it was, like the necessary law of nations, established by nature, but in a different manner. The necessary law is 'a sacred law which nations and sovereigns are bound to respect and follow in all their actions', while the voluntary law is 'a rule which the general welfare and safety oblige them to admit in their transactions with each other'11 And whereas the necessary law is based on the natural principle of self-perfection, the voluntary law accounts for what nations need to tolerate by necessity in order to avoid greater evils. In the hands of Vattel, the law of nations became what Grotius had suggested when submitting it to a free and arbitrary will, that is, more an issue of political prudence than a part of the system of natural law..$^{12}$ In interstate relations there

For a more thorough account of this point, see Ian Hunter: 'The Law of Nature and Nations,' in The Routledge Companion to Eighteenth Century Philosophy, ed. Aaron Garrett (London and New York: Routledge, 2014), 578; see also Stephen C. Neff, War and the Law of Nations. A General History (Cambridge: Cambridge University Press, 2005), 96-102.

10 Emer de Vattel, Le droit des gens (1758), preface (not paginated). Here quoted from the anonymous English translation of 1797, ed. Béla Kapossy and Richard Whatmore, The Law of Nations (Indianapolis, IN: Liberty Fund, 2008), 78.

11 Vattel, The Law of Nations, 14, 17. Regarding the voluntary law of nations, see also Simone Zurbuchen: 'Emer de Vattel on the Society of Nations and the Political System of Europe,' in System, Order, and International Law, ed. Stefan Kadelbach, Thomas Kleinlein and David Roth-Isigkeit (Oxford: Oxford University Press, 2017), 263-282.

12 This transition from Grotius to Vattel is outlined in Koen Stapelbroek, 'Universal Society, Commerce and the Rights of Neutral Trade,' in Universalism in International Law and Political Philosophy, ed. Petter Korkman and Virpi Mäkinen (Helsinki: Helsinki Collegium for Advanced Studies, 2008), 63-89, here 77-78. See also Ian Hunter, 'Vattel's Law of Nations: Diplomatic Casuistry for the Protestant Nation,' Grotiana 31 (2010), 108-140, and T.J. Hochstrasser, Natural Law Theories in the Early Enlightenment (Cambridge: Cambridge University Press, 200o), 180-182. 
are no higher principles of justice, only the conscience of a sovereign ruler well aware that in matters concerning the prosperity of the state he is the sole arbitrator.

This can explain the lack of references to Grotius or Vattel in the DanishNorwegian tradition until Schlegel introduced the positive law of nations in the 179os. By turning jus gentium into a matter of political statecraft or diplomatic casuistry, they had made it unfit as a topic for university lectures. But as long as these lectures were based on the conviction that the law of nations was part of natural law, it was possible to maintain a necessary distance to the arcana imperii. It is also worth noticing that until the end of the century lectures on the law of nations did not present it as an independent topic, but always in conjunction with jus publicum. ${ }^{13}$ This was the discipline where different kinds of governmental potestas were treated, including the right and power to engage in matters external to the state, which was part of potestas executoria - as were also jus foederum publicorum and jus belli et pacis. ${ }^{14}$ In its general form, jus publicum was supposed to show how things ought to be, regardless of how they actually were. In an introduction to the study of law, Professor Peder Kofod Ancher (1710-1788) bluntly denied the existence of a jus publicum particulare pertaining to Denmark-Norway, because the limitations that the Royal Law of 1665 put on the sovereign power were not sufficient to form a separate juridical discipline; and the purpose of it all would only be to show the absolutist state's 'proper nature and its correspondence with the principles of general public law'. ${ }^{15}$ However, with the publication of a series of lectures on jus publicum by the late Professor Andreas Hojer (169o-1739), something akin to what Kofod Ancher found unnecessary actually turned up. According to Hojer, an understanding of the Danish-Norwegian constitution required knowledge not only of law, but also of geography, pragmatic history and genealogy as well as knowledge of the alliances that throughout history had been made with other governments. Two topics treated by Hojer were the Sound dues at Øresund and Denmark's jus dominium over the Baltic Sea. The right to the dues rested on '[t]he consent of all sea powers, that is: Holland, France, England, Spain' and 'the Danish King's willingness and ability to defend vessels passing through the

13 The last series of lectures on jus publicum and the law of nations joined together was held at the University of Copenhagen in the winter of 1795-1796 by professor C.U.D. von Eggers (1758-1813). The lectures were published under the title Institutiones juris civitatis publici et gentium universalis (Copenhagen: Proft et Storch, 1796).

14 Ibid., $\$$ 98-111.

15 Peder Kofod Ancher, Anviisning for en Dansk Jurist angaaende Lovkyndigheds adskillige Deele, Nytte og Hielpemidler, 2nd ed. (Copenhagen: Ludolpf Henrich Lille, 1777), 20. 
Sound against pirates'. The jus dominium over the Baltic Sea was likewise due to the successful fight against pirates, which had made other sovereign powers recognize Denmark as the Baltic Sea's 'defender and master.' ${ }^{16}$

What Hojer covered here was not current international law; it was still a part of jus publicum and the practice of wise government. Apart from the king's duty to promote salus populi in accordance with proper rules, there was still no autonomous international legal system in existence and no legal sources independent of what the king himself regarded as a reasonable way to exercise his sovereignty. Nevertheless, it was the results of such exercises - i.e. treaties and interstate agreements, or more precisely, conventional and customary law that eventually became the backbone of the positive law of nations. Whereas the foundation of the discipline was the conviction that the practice of diplomacy was also an important part of the law of nations, as Vattel had suggested, its content was the compilation of the newest European state practice, which, from the 1770 os on, had been a part of German Staatsrecht. ${ }^{17}$ Christian Ulrich Detlev Von Eggers still anchored his lectures on jus publicum and the law of nations in the traditional frame of natural right, but when he explained the different kinds of potestas he pointed to the Allgemeines Gesetzbuch für die Preußischen Staaten (1792). In his presentation of the positive law of nations, Schlegel augmented the German connection by numerous references to Johann Jakob Moser (1701-1787), Karl Gottlob Günther (1752-1832) and Georg Friedrich von Martens (1756-1821). In the textbook he later wrote as a guide to his lectures at the Naval Academy, Christian Krohg took the matter one step further by including excerpts from treaties and agreements in order to explain what the positive law of nations was all about.

\section{Towards a New Understanding of the Law of Nations}

The late 179os witnessed a growing interest in the law of nations at the University of Copenhagen. Whereas the decade had begun with the introduction of Kant's moral and legal philosophy, attention now turned to issues concerning international relations. This change of focus was, no doubt, due to the outbreak

16 Andreas Hojer, Jus Publicum det er Stats-Ret eller Statsforfatning og Rettigheder for Danmark, Norge og Fyrstendommene forklaret ved private Forelcesninger eller Kollegio (Christiania: Jens Ørbek Berg, 1783), 9-12.

17 Martti Koskenniemi, 'Into positivism: Georg Friedrich von Martens (1756-1821) and Modern International Law,' Constellations 15 (2008): 190-191, and 'The Advantage of Treaties: International Law in the Enlightenment,' Edinburgh Law Review 13 (2009):27-67. 
of the French Revolutionary Wars and the events leading to the founding of the Second League of Armed Neutrality in 1800 . The problems now confronting the jurists were a matter of public interest in the same way that the hotly debated Kantian philosophy had been. But whereas this debate had gained momentum because the philosophy in question challenged an established intellectual culture, international matters were strictly legal and political. The most important agent of this change of focus was Professor Schlegel. As editor of the leading legal periodical Astrcea, he filled its pages with issues of legal philosophy until 1799, when an increase in space given over to matters concerning the law of nations became noticeable. ${ }^{18}$ And although his textbook on natural law was at the outset an attempt to found the scientific legal edifice on philosophical principles, he had ended it with an introduction to the positive law of nations - a discipline that was not only unknown to the broader public, but also at odds with the philosophical principles he had introduced at the beginning of the book. But Schlegel was not alone in his quest for a new understanding of the law of nations in Denmark-Norway.

In the summer of 1796 the University's faculty of law announced that it would offer, for the first time, lectures on the law of nations, without mentioning jus publicum. That these lectures were not delivered by any of the faculty's professors, but by the adjunct Frederik Theodor Hurtigkarl (1763-1829), might suggest that the subject was not considered too important. It was not among the main subjects at the students' final exam, and it was, rather, Danish law, Roman law and jus publicum that primarily occupied the professors as part of their official duties in a faculty that remained understaffed. It was therefore decided that the adjunct at the faculty of law should no longer be occupied with only administrative tasks, but also lecture. The position of adjunct thus became a recruitment position at a time when the doctoral degree was still reserved for those who already belonged to the upper echelons of the civil service. Between 1798 and 1800 three new adjuncts were employed; two of them, Christian Krohg and Mathias Hastrup Bornemann (1776-1849), were later appointed as extraordinary professors. All applicants for the position of adjunct had to undergo a series of trial lectures and several of these were later published. In 1798 the applicants had to explain the concepts of right and duty and the means at their disposal was the Kantian philosophy. In 1799 they had to answer the following question: 'What is the holiness of envoys - and what is its extent according to both the natural and the customary law of nations?'

18 Dag Michalsen, 'Legislators, Journals, and the Public Legal Sphere in Scandinavia around 180o,' in Eighteenth-Century Periodicals as Agents of Change, ed. Ellen Krefting, Aina Nøding and Mona Ringvej (Leiden and Boston: Brill Academic Publishers, 2015), 207-208. 
The answer provided by the winner of the competition shows that the problem was approached from two angles. What the natural law of nations said about the matter called for a systematic presentation, with references to Grotius, Pufendorf, Wolff and Vattel. What the customary law of nations said about the matter was shown in a historical account, starting with Livy and ending close to the present. The candidate also presented some reflections on the relation between the two types of law: in comparing the customary law of nations to the natural law one should be cautious, he argued, because even if there are similarities between interstate relations and the state of nature, the former contain at least 'an analogon of juridical security'. The mixture of 'juridical wisdom, politics and coutumes' that is normally referred to as the customary law of nations is a result of sound human reasoning that could be traced back to the ancient conception of jus feciale, 'without which no dealings between nations was possible.19 There had to be a way to approximate the two parts of the law of nations. The same eagerness to dissolve problems or discrepancies through philosophical formalization was also present in Bornemann's later attempt to sketch a set of rules for the visitation of neutral vessels and the rights of convoys in wartime. Although Krohg recommended this work to his students at the Naval Academy, its content was too abstract for the practical needs of future naval officers. ${ }^{20}$

Few details are known about Krohg's appointment to adjunct in 1800; and although trial lectures were once again held, none were published. It is also far from clear why the University sent the new adjunct to lecture at the Naval Academy and not Bornemann, who had already proven himself capable of dealing with issues of the law of nations. The most probable answer is that Krohg possessed comprehensive knowledge of foreign legislation and hence, unlike Bornemann, who was inclined to abstract speculations, was considered better suited to teach at an institution where the students needed to learn how to find their way through repositories of diplomatic and treaty practice. How to provide the cadets at the Academy with the necessary skills was, however, a question that Krohg had to solve on his own, because the

19 Mathias Hastrup Bornemann, 'Prøveforelæsning over det Spørgsmaal: Hvad forståes ved Gesandteres Hellighed, og hvorvidt strækker den sig, saavel efter den naturlige som sædvanemæssige Folkeret?', Minerva (180o): IV, 36, 52, 63.

20 Mathias Hastrup Bornemann, Over den brugelige Visitation af neutrale Skibe og konvojen, og et Middel til at hœeve begge ved en almindelig og garanteret Søhandelsfolkeret (Copenhagen: Thiele, 1801), translated into German as Über die gebräuchliche Visitation der neutralen Schiffe, und über die Convoi, nebst einem Mittel, beyde durch ein allgemeines garantirtes Seehandels-Völkerrecht zu heben (Copenhagen and Leipzig: Schubothe, 1801). 
law of nations had not previously been among the teaching subjects at the institution.

The Royal Danish Naval Academy was established in 1701 and soon became the single avenue to a naval officer position in Denmark-Norway. In order to understand the role of the Academy, one must take into consideration that from the end of the Great Northern War (1721) and until the Battle of Copenhagen (1801) the Danish-Norwegian state had enjoyed a period of relative peace. ${ }^{21}$ And although the decision to introduce the law of nations at the Academy predated the recent hostilities, it was clearly called for by international political events. Thanks to its position as a neutral power, Denmark-Norway had throughout the eighteenth century expanded its commercial interests, and its merchant fleet was about to become a main European carrier. As a result, stronger demands were put on the navy to protect merchant ships from pirates or belligerent nations. This need for protection had to do with the fact that, despite a great number of legal and diplomatic attempts to solve the problem, there was no generally acknowledged practice concerning the rights of neutral vessels. ${ }^{22}$ From a Danish-Norwegian point of view, the core of the problem was the way Britain handled neutral shipping. In the 179 os the British attitude hardened, triggered by the suspicion that neutral vessels were supplying France with much-needed goods. In 1798 two Swedish convoys were arrested by the British Royal Navy in the Channel and in 1800 a Danish convoy and the naval ship guarding it were led to a British port. ${ }^{23}$ In his response to a verdict passed by the High Court of Admiralty in Britain in one of the Swedish convoy cases, Professor Schlegel defended the rights of neutrals according to what he regarded as the established principles of the law of nations. He hoped that his investigation would 'render the rights of neutral commerce more respected by the belligerent Powers, and the voice of justice in the clamour and tumult of war more intelligibly heard in cases where the whole property of industrious and peaceable citizens is

21 For an account of the Naval Academy and a comparative study of naval education in Denmark, Sweden and England, see Evan Wilson, Jacob Seerup and Anna Sara Hammar, 'The education and careers of naval officers in the long eighteenth century: an international perspective,' Journal for Maritime Research 17 (2015): 17-33.

22 Silvia Marzagalli and Leos Müller, 'In apparent disagreement with all law of nations in the world: Negotiating neutrality for shipping and trade during the French Revolution and Napoleonic Wars,' International Journal of Maritime History 28 (2016): 112.

23 Ibid., 116. See also Pierre Pourchasse, 'Danish shipping in the Mediterranean during the Revolutionary wars (1793-1795),' The International Journal of Maritime History 28 (2016): 165-179, and Ole Feldbæk, 'The Anglo-Danish Convoy Conflict of 180o: A study of small power policy and neutrality,' Scandinavian Journal of History 2 (1977): 161-182. 
probably at stake', but he doubted that the counter-party would pay heed to his arguments. ${ }^{24}$

As he did with Bornemann's treatise on visitation, Krohg also recommended Schlegel's work to his students at the Naval Academy. But whereas Bornemann's work was too abstract and philosophical, Schlegel's resembled the work of an expert, treating the relevant parts of the natural law of nations since Grotius and revealing an intimate knowledge of current treaties and agreements. Krohg's objective as teacher at the Academy had to be more modest and take into account the level of instruction already provided in subjects of a nontechnical character. The naval articles for the shore service (1756) stated that scientific knowledge was paramount for being a good officer, and the Academy had to provide the cadets with sufficient knowledge not only of tactics, navigation, gunnery and applied mathematics, but also of (modern) history and geography. According to Carl Frederik Dichmann (1763-1806), teacher of history and geography at the Academy from 1796 to 1806, the purpose of these two subjects, joined together, was to provide knowledge of the contemporary world and its historical prerequisites - geography by describing territories belonging to different states, history by outlining the origins of various territorial rights.

\section{4}

Krohg's Lectures 1: the Founding Principles

Whereas history and geography provided knowledge about the distinctiveness of modern states, Krohg started his lectures from the opposite angle, by explaining what a state or a nation is. A state is an association that individuals had entered into for protection and security and this association was also a legal state, involving enforceable rights and duties. But this legal state is internal to the state and hence not binding on other states or individuals not counted as citizens. To believe otherwise would, according to Krohg, 'in most cases contradict every independent nation's original purpose of founding the state.'25 This is not to say that interstate relations were devoid of legal regulations, only that these were different from those pronounced in a state's positive legislation. In order to understand the nature of these regulations, natural law had come to regard the state as a moral person and the relationship between states as akin to

24 J.W.F. Schlegel, An Examination of the Sentence in the Case of the Sweedish Convoy Pronounced in the High Court of Admiralty of England on the Eleventh of June, 1799 (London: W. Wilson, 1800), 115.

25 Christian Krohg, Forsøg til en Ledetraad ved Forelsninger over Folke-Retten (Copenhagen: Andreas Seidelin, 1803), § 3 . 
the relationship between individuals in the state of nature. But this application of natural law is not sufficient. Rather than being content with the commands of natural law as a guide to interstate relations, one must realize that these relations are of a more complicated character. Hence they need a more thorough treatment than what can be provided by a 'general legal science.'. ${ }^{26}$

Even if nations are not living under any human superior and do not acknowledge a common legislator or regent, they are by human reason itself entitled 'by interrelated consent to decide certain rules for their actions, that as laws will bind them either forever or for a certain time and whereby their original legal relationship, established by reason itself, is more exactly determined or even changed insofar as this change does not exceed the limits that the purpose of the state and human dignity have declared to be unchangeable., ${ }^{27}$ These arbitrary provisions are the subject of the positive law of nations; and according to the different means whereby nations announce their consent, this discipline can be divided into a) the law of treaties, i.e. consent founded on real agreements, and b) the law of custom, i.e. consent founded on previously repeated actions. These were also two of the three sub-disciplines that according to Vattel made up the positive law of nations. As for the third one, the voluntary law, Krohg never uses the term nor does he seem to regard the content treated under that term as an issue of its own. It is, however, worth noticing Vattel's remark about how and why the decisions of the necessary law of nations 'must be modified by the voluntary law'28 - and in one of his later lectures Krohg paid due attention to the way treaties and agreements put limitations on the commands of the natural law of nations, as will be seen below.

Concerning the difference between the natural and the positive law of nations, Krohg points to the definitions presented in an encyclopedia of the sciences by the German philosopher Wilhelm Traugott Krug (1770-1842): a science is natural when its content and scope are determined by 'the nature of the objects themselves to which they refer, and by the nature of the human intellectual capacity as such', whereas it is positive when 'in regard of its truth and validity it is conceived as depending on any kind of arbitrariness.'29 Besides this formal difference Krohg also underlines a difference in content:

The natural law of nations takes place as soon as we imagine the founding of states - and must be applied to all, and between all, nations; the

$26 \quad$ Ibid., $\$ 4$.

27 Ibid., $\$ 6$.

28 Vattel, The Law of Nations, 78.

29 Wilhelm Traugott Krug, Versuch einer Systematischen Enzyklopädie der Wissenschaften. Zweiter Theil (Jena: J.G. Voigt, 1797), § 228. 
positive law of nations can only oblige nations that have already entered an association that must be regarded as binding or to the extent that they acknowledge the binding power of customs. The commands of the natural law of nations are, like its very foundation, reason itself, eternal and unchanging.

The commands of the positive law of nations are, on the contrary, changeable, depending on what the will and the needs of nations decide or demand.

The natural law of nations is not dependent on the positive, but the positive on the natural. The natural law of nations is a philosophical science; the positive is a purely historical science. The former decides what ought to happen without regard to what has happened; the latter most often derives the rules for what ought to happen from what has happened (through treaties, customs). ${ }^{30}$

Krohg admits a lack of certainty in the system of the natural law of nations, but this is due to a disagreement between different authors on specific topics and not a flaw of the system itself. Even if the natural law of nations is as old as the nations themselves, its commands have been interpreted in different ways. It would therefore be beneficial for students to get acquainted with various authors' treatment of the matter, because adherents of different philosophical opinions are inclined to understand certain topics in a one-sided manner. Krohg then turns his attention back to the positive law of nations, this time as the result of historical development. Almost all nations we know from history have had some kind of relation with neighbors or strangers, and these relations have been subject to regulations. War and peace, trade and intercourse have made rules of conduct all the more necessary because increased contact between nations also raises the possibility of conflict. The purpose of this historical sketch is twofold: Krohg wants to show that, unlike the natural law of nations, the positive law of nations is the result of a certain cultural and historical development; and even if we find positive regulations between nations far back in history, these are not the subject of the positive law of nations. As an academic discipline the positive law of nations is concerned only with the treaties or associations which are still binding.

What these treaties and associations show us is the European nations' state of law, and in its systematic treatment the positive law of nations 
restricts itself to these states and their connections between themselves as well as their relations to other powers outside of Europe.

But not all of the associations known from history are of interest to us in a legal sense; only those that are still valid - and in a direct or indirect manner concern us. We rarely need to move further back than the seventeenth century when we investigate the still binding power of the treaty-bound law of nations. There are no examples of a common treaty joined by all European powers, but there are some that come close; therefore there is no common treaty-based European law of nations. We can, however, by comparing the principles upon which the main parts of the treaties are based, deduce a certain similarity - and thus presume that certain rules have been followed. Likewise we can to a certain extent deduce some common customs from the different nations' similar behavior under identical circumstances. ${ }^{31}$

The most important contributions to the discipline were not theoretical works but practical introductions, handbooks and collections of treaties running through one augmented edition after another. And when lecturing on the positive law of nations, Krohg's task was not to present theoretical knowledge to his students, but to guide them through reference works and other recommended literature. His own textbook might well be understood as an attempt to enable the students to find their way through more substantial works on the subject. ${ }^{32}$

In the first four chapters of his textbook Krohg deals with 1) some common rules according to which the nations' special legal relations should be determined, 2) the nations' property rights and territorial rights in general, 3) treatises in general and 4) envoys. Although these are classical issues in the law of nations and the two last subjects are treated in a rather traditional manner, the first two deserve closer attention. To clarify the legal relations between the nations was a task for the natural law of nations, for the simple reason that it had nothing to do with current treaties; on the contrary, it was a prerequisite to any binding agreement between nations. And here one had to cope with the same problems that had once occupied Vattel: What is the difference between

31 Ibid., $\S 8$.

32 Among the works recommended by Krohg were two important collections of treaties: Gabriel Bonnot de Mably, Le droit public de l'Europe fondé sur les traités conclus jusqu'en l'année 1740 (The Hague: Jean Van-Duren, 1746), and Georg Friedrich von Martens, Recueil des principaux traités d'alliance, de paix, de trêve, de neutralité, de commerce, de limites, d'échange etc. conclus par les puissances de l'Europe (Göttingen: Dieterich, 1791-1801). 
a sovereign state's obligations towards itself and its obligations towards other states? And to what extent can interstate obligations be regarded as something more solid than the temporary results of diplomatic casuistry or the political prudence expressed in numerous treaties and other formal agreements? While authorities on the positive law of nations tried to move beyond Vattel regarding the second problem, they simply bypassed the first by taking the difference between the two forms of obligations for granted. To regard interstate obligations as equally binding as a state's obligations to itself presupposed a political arrangement different from the existing system of sovereign states. This was a philosophical concern, like the Kantian idea of a perpetual peace or a cosmopolitan law, not a matter for jurists - and certainly not for the positive law of nations. ${ }^{33}$

Although Krohg's references to Vattel are sparse and his textbook does not include the almost mandatory sketch of the history of the law of nations, he would no doubt have accepted the statement that the Swiss had brought the law of nations back on the right track after it had lost itself in philosophical speculations, and that he thus provided the discipline with a foundation upon which to build. ${ }^{34}$ That said, Krohg has no misgivings about quoting from or referring to works of a more philosophical or utopian kind, such as a proposition presented to the French National Convention in April 1795 by Henri JeanBaptiste Grégoire (1750-1831). This proposition was at odds with the idea of a law of nations based on the European system of sovereign states and had been subject to severe criticism in sources also used by Krohg. ${ }^{35}$ Some of Grégoire's principles were abstract moral maxims that could only be implemented under conditions which, if they were present, would make the implementation unnecessary. Other principles were more dangerous, like the prohibition of alliances that violated the interests of a single nation or the suggestion that only constitutions based on the principles of freedom and equality conformed to

33 Georg Friedrich von Martens, Précis du droit des gens moderne de l'Europe (Göttingen: Dieterich, 1801), 14.

34 See Georg Friedrich von Martens, Einleitung in das positive Europäische Völkerrecht (Göttingen: Johann Christian Dieterich, 1796), § 8, and Karl Gottlob Günther, Europäisches Völkerrecht in Friedenszeiten (Altenburg: Richter, 1787), §§ 26, 27.

'Discours de Grégoire, député à la Convention nationale par le département de Loir et Cher, prononcé dans la séance de 4. Floreal an. 3. de la Rép. Francaise (23. Avril. 1795.) sur une déclaration de droit des gens à faire par la Convention nationale,' Recueil des Traités de paix, d'amitié, d'alliance, de neutralité et autres conclus entre la République francaise et les différentes Puissances de l'Europe depuis 1792 jusqu’à la paix générale. Premiere Partie. Septembre 1791 - Aout 1795 (Hamburg: Fréderic Perthes; Paris: Treuttel et Würtz, 1796), 9-25. For the criticism of Grégoire, see Martens, Einleitung, V-XVI. 
the rights of peoples. The constitution of a state was a matter for nobody but the sovereign state itself. Whatever the status of the principles of the natural law of nations, they were not something a state could invoke in order to take action against another state. This is the unequivocal message in Krohg's outline of how the rules regulating legal relations between nations maintain the balance between equality and sovereignty.

The internal organization of every state regarding the legal relations between the ruler and the subject or between subjects is an issue that only concerns the state itself and is dependent upon its will. The laws and the form of government are therefore, according to the advice of policy and wisdom, different in different states. But this difference has no direct influence on the law of nations. The law of nations can therefore not embark on these matters that first and foremost belong to public law and political prudence without transgressing its boundaries. ${ }^{36}$

Being free and independent, the nations do not acknowledge a common superior except God and the law of justice and right. The interpreter of the law is the single nation itself, and in its contentions with other nations it is also entitled to pass its own verdict - and to implement it. But this must be done according to the principles of reason, which, on the one hand, highlight security, peace and perfection as the ultimate purposes of nations, and, on the other hand, maintain that no nation is entitled to pursue these purposes in a way that interferes with the rights of others. Between nations there is legal equality; and according to the natural law of nations, a single nation cannot have other or more extensive rights than another nation would be entitled to under similar circumstances. Supremacy in power, higher culture, enlightenment or refinement does not give a nation any rightful advantages over others. On the contrary, because every nation has a natural inclination to pursue justice and virtue, it can claim respect from others just as well as any citizen can demand to be respected as a human being. Mutual respect is a prerequisite for any kind of cooperation and interstate sociality - and with a reference to Vattel, Krohg declares that the only natural limit to the nations' right to interact with each other is their own security. ${ }^{37}$

Before closing his chapter on legal relations between nations Krohg introduces the following problem: does the fact that the positive law of nations

$36 \quad$ Krohg, Forsøg, § 20.

37 Ibid., § 27; see also Vattel, The Law of Nations, Preliminaries, §§ 11-12. 
presupposes an advanced stage of cultural development also have consequences for relations between more developed and less developed nations? According to Krohg there is no doubt that historical circumstances have created social ties between the European states that are much closer than any ties they might have with other nations. Bypassing the fact that many of the authors he elsewhere refers to insist that whereas Turkey is a European nation it is not on the same cultural level as the rest of Europe, Krohg emphasizes that the cultural ties between European nations do not make them into a society that is so distinct from all other nations that it has had or has its own positive law of nations. ${ }^{38}$ Philosophers and travel authors use culture, enlightenment and justice as a benchmark in order to distinguish between ethical, barbarian and savage nations. Whereas the European nations ascribe the title of moral to themselves,

[t]hose nations, on the other hand, that normally do not pay heed to the commands of the general law of nations, except through specific promises to do so, or that are unwilling to acknowledge the binding power of European customs, are in Europe given the name of barbarians; but this denomination cannot deny them the protection of the general law of nations. ${ }^{39}$

Although Krohg later refers to barbarians and savages, he seems to use the terms interchangeably and does not elaborate the distinction between them in the way that was then prevalent. ${ }^{40}$ According to this distinction the barbarian states might not meet the European moral and cultural standards, but it was still possible to make agreements with them, as a number of current treaties illustrated. Savages, on the other hand, appeared to lack law, liberty and civilization and hence to be devoid of all means for cooperation. It makes perfect sense, therefore, that when Krohg later returns to barbarians and savages, it is in his account of the concept of terra nullius: neither the natural nor the positive law of nations prohibits a nation from taking possession of a territory over which no other nation claims ownership or which has been abandoned by its previous owner. All nations do not enjoy the same level of culture, but a lack of culture is not a crime leading to the loss of property

38 See Jennifer Pitts, 'Empire and Legal Universalisms in the Eighteenth Century,' The American Historical Review 117 (2012): 101-104.

39 Krohg, Forsøg, § 28.

40 For a meticulous examination of these concepts, see J.G.A. Pocock, Barbarism and Religion IV: Barbarians, Savages and Empires (Cambridge: Cambridge University Press, 2005). 
rights. According to the dictates of reason, the use of a possession is entrusted to the owner's discretion insofar as it does not intend to harm others, and no nation is entitled to expropriate an uncultivated territory within the borders of another nation.

The possessions of the so-called savage nations can thus not be subject to the states' right to expropriation. And even less can differences in religion, forms of government etc. give other nations such rights. The injustices that the European nations have made themselves guilty of in this regard are common knowledge, and the guardian angel of humanity seems, in our time, to have prevented such violent deeds from achieving the name of justice. The present treaties and arrangements of the European nations explicitly presuppose that the territory of the barbarian or savage belongs to him in the same sense that it can become European through legal negotiations. ${ }^{41}$

Whereas Krohg here seems to run barbarian and savage nations together, recognizing both as legal persons, they do not fully meet the standards of moral nations. In his chapter on treaties he explains to his students that the united voices of politics and justice tell the moral nations to keep their treaties with barbarian states 'with twice the normal meticulousness.' ${ }^{42}$ Although he does not explain why this is so, any explanation would confirm the indelible difference between moral and barbarian nations. The rights and duties prescribed by the natural law of nations might apply to all nations alike, but the reliability or trustworthiness of barbarians and savages remain an open question. Despite all arguments for the universal validity of the law of nations, the fact that he introduces the difference between types of nations shows the extent to which Krohg adhered to the view that the legal relations between nations is modelled on a European cultural self-understanding. And it is no coincidence that this is the only place in his lectures where he refers to works that are not strictly juridical, but general surveys of the uniqueness of European culture. ${ }^{43}$

41 Krohg, Forsøg, § 35. See also Vattel, The Law of Nations, book II, chap. 7, §§ 86-88. Most of what Krohg has to say about this subject seems to be lifted from Vattel.

42 Krohg, Forsøg, § 62 .

43 The works are Daniel Jenisch, Cultur-Character des achtzehnten Jahrhunderts, nach bürgerlicher Verfassung, Sittlichkeit, Kunstgeschmack und Wissenschaft (Berlin: Verlag de Königl. Preuss. Akad., 180o), and Friedrich Gentz, Von dem politischen Zustand von Europa vor und nach der Französischen Revolution (Berlin: Heinrich Frölich, 1801). 
Little of what Krohg had said so far suggested that his audience was not students of law at the University, but cadets at the Naval Academy. However, this changes in the last three chapters of his textbook, dealing with trade and shipping (chap. 5), the legal relations between belligerent nations (chap. 6) and the duties and rights of neutral nations (chap. 7). These issues were of great relevance to his audience and they are presented in a manner different from the rest of the book. Although Krohg had insisted that the natural and the positive law of nations should be treated together, his last chapters are first and foremost about the latter. The very order of these chapters also illustrates a general trend in the literature on the law of nations in the late eighteenth century: the concept of neutrality is treated not only in the light of warfare but also in the light of trade and shipping, and it is regarded as a topic of its own.

After telling his students that need and industry once gave birth to trade between the nations, Krohg underlines that laws were introduced in order to prevent this enterprise from evolving into fighting or injustice. For a naval officer it is just as important to learn the rules of justice in shipping and trade as it is to know the trajectory of a bullet and the power of stormy waves. ${ }^{44}$ The rules to be obeyed are the law of nations, royal commands, current treaties and custom. Krohg here cites numerous excerpts from treaties and trade agreements, not only between European powers but also between Denmark-Norway and other European states as well as the Barbary states, i.e. the North African nations of Morocco, Algiers, Tunisia and Tripoli. The signing of treaties with these nations in the 1740 os and 175 os was of great significance for the sea trade, because it allowed Danish-Norwegian ships to sail through the Strait of Gibraltar and carry goods across the Mediterranean Sea.

In addition to the rules specified in treaties or agreements there were two sets of regulations that a Danish-Norwegian naval officer had to know about. The first was the unwritten set of rules for ceremonial conduct at sea, including the proper way to salute, the striking of sails, the hoisting and lowering of flags etc. According to Krohg this set of rules was 'in its original form sensible, but had through its many amendments become something of a bone of contention'. The more complex the rules, the more difficult it was to avoid mistakes that could provoke an opponent. ${ }^{45}$ Some of these rules were also specified in

$\begin{array}{ll}44 & \text { Krohg, Forsøg, } \$ 83 . \\ 45 & \text { Krohg, Forsøg, } \$ 95 .\end{array}$ 
the Danish-Norwegian naval articles of 1752, which was the second set of regulations here in question.

Moving from the regulations of peacetime to the rules of wartime, Krohg defines war as 'the state in which the nations find themselves after declaring the general state of mutual security to be repealed, and the nations have made manifest their will to inflict damage upon each other by applying coercive power. ${ }^{46}$ Because peace and the enforcement of right are the purpose of war, warfare is a means permitted by reason itself in order to achieve this purpose. It is, however, important to notice that, in the same way as reason, by prescribing a purpose to man, does not endorse whatever means could be considered as convenient in order to achieve this purpose, there are also rules according to which war between nations ought to be waged. But even if the nations, and especially those that wish to deserve the title of moral, acknowledge these rules, they are not to be found in any general treaty of warfare but are the rules of custom and the sacred commands of reason.

According to Krohg, war is the circumstance, or situation, that occurs as a result of a state's will to use extraordinary means to pursue right and peace. Although he does not mention Grotius here, he nevertheless seems to follow a Grotian argument according to which war has little to do with the law of nature, but all the more with the law of nations, regarded as voluntary: 'Custom has so prevailed, that not the Act of Hostility, but the State and Situation of the contending Parties, now goes by that Name; so that War is the State or situation of those [...] who dispute by Force of Arms.47 This means that war does not refer to specific acts: it refers, rather, to the circumstance in which these acts take place. But as Krohg further explained to his students, even if war repeals the mutual security that accompanies peace and overrules a number of the duties imposed upon peaceful nations, this does not mean that it puts an end to all binding relations between nations. There are limits to what you can do in war, and it is 'the sacred commands of custom, reason and humanity' that must guide the warrior. ${ }^{48}$

Therefore, an enemy, as a human being, can still demand a certain amount of respect - despite the unjust cause of his nation. [...] To despise

\footnotetext{
$46 \quad$ Krohg, Forsøg, § 100.

47 Grotius, The Rights of war and peace, book I, chap. 1, § II, 134; see also Vattel's definition: 'War is that state in which we prosecute our right by force'. The Law of Nations, book III, chap. I, § 1, 291. For a thorough treatment of this issue, see Neff, War and the Law of Nations, 138-140. 
individual members of a nation just because the nation is our enemy is a behaviour that cannot be justified in any reasonable manner. The warrior defends his fatherland, but the enemy warrior that attacks him, is not his personal foe. ${ }^{49}$

The secondary rights to exercise violence in wartime are, however, limited in scope - and they should also, ideally, be limited in degree. In the first place, one must notice that the purpose of war is not individual gain; war is waged by the state and is a matter between states. It is the regent who declares war and decides who among his underlings are entitled to perform hostile actions and under what conditions. In the second place, it is not for the natural law to decide which coercive measures a belligerent party should make use of. This question must be handed over to the parties themselves and be answered in light of what the occasion demands. But because the right to use coercive measures is prompted by necessity, reason recommends that neither party resort to harsher measures where more lenient ones are sufficient. And some measures, such as the use of traitors or assassins and the poisoning of wells, are not to be used under any circumstances. Reason cannot endorse, nor can nations regard as legal, actions that will exterminate righteousness and virtue. ${ }^{50}$

Krohg then turns to an issue concerning naval warfare. Having made clear that the natural law of nations does not permit private citizens to exercise hostilities and prohibits assaults, attacks or maltreatment of citizens of a hostile state as long as they remain peaceful, he adds that this rule in general also protects private property. 'The positive law of nations has, however, introduced certain exceptions to this rule by allowing that merchant vessels from hostile states that are encountered at sea by warships or privateers from the counterparty, can be arrested, seized and brought before a prize court.51 When telling his students that only regular armed forces were entitled to attack or open hostilities, Krohg made an exception for those who had received special permission through a letter of marque, i.e. privateers. This kind of engagement in maritime warfare by commission had developed during the Middle Ages, and in the eighteenth century a large part of the total military force at sea were privateers. In a Danish-Norwegian context this system was well known from the Great Northern War (1709-1720), and it would in a few years' time be used again on a greater scale than ever. What made privateering legal in contrast to piracy was the fact that the permission was anchored in a set of generally

\begin{tabular}{ll}
\hline 49 & Ibid., \\
50 & Ibid., 102. \\
$5^{1}$ & Ibid., 103. \\
&
\end{tabular}


accepted rules. A privateer should not only seize his booty according to the terms stated in his letter of marque but also bring it before a prize court, i.e. a court authorized to decide if the booty had been lawfully captured.

What Krohg had to say about war and belligerent nations is clearly anchored in a Grotian framework. His treatment of neutrality, on the other hand, illustrates how this concept had been transformed during the eighteenth century. According to Grotius, 'it is the Duty of those that are not engaged in the War, to sit still and do nothing, that may strengthen him that prosecutes an ill Cause, or to hinder the Motions of him that hath Justice on his Side., ${ }^{52}$ And even if he did not draw the conclusion of the old doctrine of just war - that because one of the belligerents will have a just cause for war, it is morally reprehensible not to support him - Grotius still understood 'neutrality' from the vantage point of war. ${ }^{53} \mathrm{Krohg}$, on his side, approached neutrality from two different angles: one of them was, of course, the concept of war; the other, and more important, was maritime trade in peacetime. Here he followed what had become the prevalent understanding of neutrality. Whereas the contractual understanding of war acknowledged the right of third parties to remain neutral, it was far from clear whether they also had the right to carry on business as usual. Among the most important contributors to this new understanding of neutrality was the person whom Schlegel had described as 'the great champion of neutral privileges', the Danish-German jurist Martin Hübner (17231795). ${ }^{54}$ Although Krohg only has one single reference to Hübner's De la saisie des bâtimens neutres (1759), his treatment of the issue suggests that Hübner's importance is far greater than the lack of further quotations or references might suggest. After all, Hübner was not only the author of an influential book on neutrality but had also been an advisor to the Danish-Norwegian minister for foreign affairs and the architect of the nation's policy of neutrality, J.H.E. von Bernstorff $(1712-1772) .55$

$5^{2}$ Grotius, The Rights of War and Peace, book III, chap. 17, § III.1, p. 1525; see also Koen Stapelbroek, 'The Rights of Neutral Trade and its Forgotten History', in Trade and War: The Neutrality of Commerce in the Interstate-System, ed. Koen Stapelbroek (Helsinki: Helsinki Collegium for Advanced Studies, 2011), 3-13.

Grotius never uses the term 'neutrality' but talks about 'eorum qui a bello abstinet'. And although the chapter is entitled 'Of Neuters in war', this is a translation of 'De his qui in bello medii sunt'.

54 Schlegel, An Examination, 132.

55 The literature on Hübner is sparse, but a fine introduction to his major work is Nora N. Leerberg, The Legal Politics of Neutrality in the Age of Privateering. Martin Hübner's Law of Neutrality and Prize (Oslo: Dreyer, 2015). See also Stapelbroek, 'Universal Society, Commerce and the Rights of Neutral Trade'. 
Krohg opens his chapter on neutrality with half a dozen pages of references to relevant works on the subject, before telling his students that a neutral nation resides in a state of neutrality and therefore has not only duties towards others but also rights of its own. ${ }^{56}$ Here it is crucial to distinguish between a nation's right to stay neutral and its rights as neutral. It is for a nation itself to decide if a just cause of war is present and if it should help another nation against its enemies, but it is not compelled to do so unless an explicit promise has been given. Peace is the natural state of nations and every nation must be regarded as peaceful and neutral and also be treated as such, unless it has proved otherwise. Against this background it should be rather easy to point out the rights and duties of the neutral nation.

Because the neutral nation lives in peace with the belligerents, it should enjoy all the rights and all security that characterizes a peaceful relationship in general, as it should also fulfill all the duties that the law of nations imposes on a nation that lives in peace with others. The same liberty of trade and commerce, the same security on its own and on foreign territory in regard to persons and goods that behooved it under a common peace, should still be ascribed to it after the outbreak of war between other nations, towards which the neutral should enjoy the safety of a peace that it in no way can be presumed to have broken. ${ }^{57}$

This is the status of a neutral nation according to the natural law of nations. But because treaties and custom have long since put restrictions upon the rights of neutral nations, it is important to determine whether the positive law of nations has overruled these rights or whether these restrictions should be modified according to the general freedom of nations. And even if there is no general agreement concerning neutral nations' legal relations with belligerents and hence no unequivocal specification of the rights and duties in question, neutral nations have no doubt, by consent, renounced the general freedom of trade and thus acknowledged principles apparently alien to the natural law of nations.

Neutral nations agree not to supply belligerent nations with certain goods that were given the name of contraband of war. In treaties it was decided whether the principle: free ship, free goods was valid or not. The investigation or visitation that neutral vessels, under certain conditions,

$56 \quad$ Krohg, Forsøg, § 126.

57 Ibid., §127. 
should submit to, was given a more determined form, and rules according to which the neutrality of the vessel and the legality of the cargo should be proven, were fixed. ${ }^{58}$

Using this historical fact as a vantage point, Krohg turns to the positive law of nations, leaving the natural law of nations aside because it has no room for concepts like contraband of war or blockade. In general, 'contraband' was goods 'that immediately and in their present form are destined for waging war'; but to qualify as contraband these goods had to be destined for a port belonging to a belligerent power, and no goods 'which are not explicitly regarded as contraband of war in treaties, can be regarded as such.59 Concerning blockades, the natural law of nations acknowledged the right of belligerent nations to deny neutral ships access to a certain port even if they did not carry contraband. But in order for a port to be recognized as blocked, two further criteria had to be met:1) the blockade had to apply to a specific port and 2) there had to be warships present in order to render attempts to access the port a dangerous adventure. ${ }^{60}$ Whereas the concept of contraband put limits on the principle of free ship, free goods, a blocked port limited the freedom of navigation. On the other hand, both restrictions were beneficial to neutral nations in a twofold manner: 1) they introduced specifications that made it easier to understand the rules of play, and 2) they were countermeasures against 'the interventions that belligerent nations had allowed themselves in regard to neutral nations' natural and treaty-bound rights'. Here Krohg refers to the Russian Declaration of 28 February 1780 where Tsarina Catharina II presented 'a draft of a sea-law that included the most important principles concerning neutral nations' rights and duties towards belligerents'. ${ }^{61}$ In the absence of a universal agreement, these principles became the foundation upon which a viable politics of neutrality was conducted.

Almost all the sea-powers that these principles were announced to, gave them their consent; and when some nations united in order to render them valid through armed force, the system of armed neutrality so renowned to the recent naval law of nations was founded - and its main principles have since then been repeated and renewed in numerous treaties. [...] Even those powers between whom no mutual agreements

$5^{8} \quad$ Ibid., $§ 135$.

$59 \quad$ Ibid., § 136, § 138.

$60 \quad$ Ibid., § $138, \S 140$.

$61 \quad$ Ibid., $§ 138$. 
concerning the right of the neutral flag have been concluded are committed to acknowledge the maxim: free ship, free goods; provided those powers, in one way or another, have also acknowledged the validity of the armed neutrality and its compliance with the natural law of nations. ${ }^{62}$

The political context of the Russian Declaration was beyond the scope of Krohg's lectures. Regarded as a contribution to the positive law of nations, it was sufficient to present the principles upon which the League of Armed Neutrality was founded as a reaffirmation of the rights of neutral nations, and support this view with references to recent treaties and agreements. The students were not told that this was an alliance of naval powers (Russia, DenmarkNorway and Sweden), founded in order to protect neutral shipping against the British Royal Navy's wartime policy during the American War of Independence $\left(1775^{-1783}\right)$ and the Anglo-French War (1778-1783) - a policy that included coastal blockades and unlimited search for contraband. In his aforementioned response to the High Court of Admiralty, Schlegel had complained that the British in their maritime wars relied on their superior naval power, and sought 'to extend the contraband articles of war as far as possible, in order thereby to distress their enemies to the utmost of their power.' ${ }^{63}$ It was against a conception of contraband that included not only goods that directly and in their actual form served the purpose of war, but also goods that indirectly or occasionally could do so, that treaty-bound specifications were aimed. The restricted concept of a blockade was, likewise, targeted against the British attempt to cut off neutral maritime vessels from entire coastlines.

Although the League was dissolved in 1783 , its principles retained their validity and when the same naval powers founded a second League of Armed Neutrality during the War of the Second Coalition (1798-1802) they reconfirmed the political programme of $178 \mathrm{o}$. But this time the British government regarded the League as an alliance with France and attacked Denmark-Norway, destroying parts of its naval fleet in the first Battle of Copenhagen in April 1801 and forcing it to withdraw from the League. ${ }^{64}$ By then the League itself was about to collapse, and after negotiations between Britain and Russia a convention was signed in June 1801 and later joined by Denmark-Norway. Here two new principles forwarded by the League were confirmed: 1) that seizure of neutral

62 Ibid., § 138, § 139.

63 Schlegel, An account, 94-5.

64 See Ole Feldbæk, Denmark and the Armed Neutrality $1800-1801$ (Copenhagen:Akademisk Forlag, 1980), and The Battle of Copenhagen 1801. Nelson and the Danes (Barnsley: Leo Cooper, 2002). 
ships required a just cause, and 2) that merchant ships under neutral convoy should not be visited by belligerent warships. Krohg's translation of a large part of the convention forms the bulk of his section on visitation of neutral ships. ${ }^{65}$ Although he thereafter adds three short paragraphs on verdicts passed on seized neutral ships, hostilities on neutral territory, and the rights of warships and privateers to enter neutral ports, he clearly regarded this convention as the last contribution to the positive law of nations and hence a natural place for his lectures to end.

Following the path that Professor Schlegel had cleared when he introduced the positive law of nations in a Danish-Norwegian context and showed that this discipline amounted to more than natural right applied to interstate relationships, Krohg in his textbook guided the cadets at the Naval Academy all the way from the principles of the natural law of nations to the most recent statements of the positive law of nations. Both teachers relied, more or less explicitly, on the theories once put forth by Grotius and Vattel and used these as a vantage point from which to approach the works of Martens and other proponents of the law of nations as a historical science. Whereas Schlegel still treated the law of nations as a part of the comprehensive system of natural right, Krohg focused on making the discipline more accessible to an audience with more practical needs. More than half of his textbook's 280 pages were in fact references, quotations or excerpts from treaties, conventions and agreements. Unlike Schlegel, Krohg was not inclined to theoretical or systematic thinking. Soon after his textbook was published he left the academic world, despite his appointment as extraordinary professor of law in 1803. Eager to seek employment in Norway, Krohg was appointed assessor in the regional high court in Trondheim in 1804 and turned his attention to practical legal matters for a while, before he once again got caught up in issues pertaining to the law of nations.

Krohg's textbook addressed future naval officers in a neutral state; after the outbreak of the Napoleonic Wars (1803-1815), however, it became more difficult for the state to maintain its neutrality. When Britain noticed that DenmarkNorway had come under severe pressure from France and Russia to pledge its naval forces to Napoleon, the Royal Navy bombarded Copenhagen in September 1807 and then seized the fleet. After the attack, Denmark-Norway entered

65 Krohg, Forsøg, § 141. 
an alliance with France through the Treaty of Fontainebleau, in October 1807. But as early as September 14, when the ruins of Copenhagen still smoldered, the government issued regulations for privateering - and more than thirty vessels were fitted out for this task in less than a month. According to the positive law of nations, prize courts were established in several towns along the Danish and Norwegian coastlines in order to supervise the privateering. One of the members of the prize court in Trondheim was assessor Krohg; and from 1810 and until it was dissolved in 1814 he served as the court's chief justice. What he had once told his students at the Naval Academy about neutrality probably occurred to him as irrelevant at this time. What he had said about the rules of privateering was more relevant than ever before.

\section{Bibliography}

Ancher, Peter Kofod, Anviisning for en DanskJurist angaaende Lovkyndigheds adskillige Deele, Nytte og Hielpemidler, 2nd. ed. (Copenhagen: Ludolpf Henrich Lille, 1777).

Bornemann, Mathias Hastrup, 'Prøveforelæsning over det Spørgsmaal: Hvad forståes ved Gesandternes Hellighed, og hvorvidt strækker den sig, saavel efter den naturlige som sædvansmæsseige Folkeret?', Minerva (1800) III: 32-72.

Bornemann, Mathias Hastrup, Über die gebräuchliche Visitation der neutralen Schiffe, und über die Convoi, nebst einem Mittel, beyde durch ein allgemeines garantirtes Seehandels-Völkerrecht zu heben (Kopenhagen und Leipzig: Schubothe, 1801).

Eggers, C[hristian] U[lrich] D[etlev] von, Institutiones juris civitatis publici et gentium universalis (Hafniae: Proft et Storch, 1796).

Feldbæk, Ole, 'The Anglo-Danish Convoy Conflict of 180o: A study of small power policy and neutrality,' Scandinavian Journal of History 2 (1977):161-182.

Feldbæk, Ole, Denmark and the Armed Neutrality 1800-1801 (Copenhagen: Akademisk Forlag, 1980).

Feldbæk, Ole, The Battle of Copenhagen 1801. Nelson and the Danes (Barnsley: Leo Cooper, 2002).

Gentz, Friedrich, Von dem politischen Zustande von Europa vor und nach der Französischen Revolution (Berlin: Heinrich Frölich, 1801).

[Grégoire, Henri Jean-Baptiste], 'Discours de Grégoire, député à la Convention nationale par le département de Loir \& Cher, prononcé dans la séance de 4. Floreal an. 3. de la Rép. Francaise (23. Avril. 1795.) sur une déclaration de droit des gens à faire par la Convention nationale,' in Recueil des Traités de paix, d'amitié, d'alliance, de neutralité et autres conclus entre la République francaise et les différentes Puissances de l'Europe depuis 1792 jusqu'à la paix générale. Premiere Partie. Septembre 1791-Aout 1795 (Hambourg: Fréderic Perthes; Paris: Treuttel et Würtz, 1796), 9-25. 
Grotius, Hugo, The Rights of War and Peace, transl. from the edition by Jean Barbeyrac, ed. Richard Tuck (Indianapolis, IN: Liberty Fund, 2005).

Günther, Karl Gottlob, Europäisches Völkerrecht in Friedenszeiten (Altenburg: Richter, 1787).

Haakonssen, Knud, 'Holberg's Law of Nature and Nations,' in Ludvig Holberg (16841754). Learning and Literature in the Nordic Enlightenment, ed. Knud Haakonssen and Sebastian Olden-Jørgensen (London and New York: Routledge, 2017), 59-79.

Hochstrasser, T.J., Natural Law Theories in the Early Enlightenment (Cambridge: Cambridge University Press, 2000).

Hojer, Andreas, Jus Publicum det er Stats-Ret eller Statsforfatning og Rettigheder for Danmark, Norge og Fyrstendommene forklaret ved private Forelcesninger eller Kollegio (Christiania: Jens Ørbek Berg, 1783).

Holberg, Ludvig, Introduction til Naturens- og Folke-Rettens Kundskab (Copenhagen: Johan Kruse, 1716).

Hunter, Ian, 'Vattel's Law of Nations: Diplomatic Casuistry for the Protestant Nation,' Grotiana 31 (2010): 108-140.

Hunter, Ian, 'The Law of Nature and Nations', in The Routledge Companion to Eighteenth Century Philosophy, ed. Aaron Garrett (New York: Routledge, 2014), 559-592.

Jenisch, Daniel, Cultur-Character des achtzehnten Jahrhunderts, nach bürgerlicher Verfassung, Sittlichkeit, Kunstgeschmack und Wissenschaft (Berlin: Verlag der Königl. Preuss. Akad., 180o).

Koskenniemi, Martti, 'Into positivism: Georg Friedrich von Martens (1756-1821) and Modern International Law,' Constellations 15 (2008): 189-207.

Koskenniemi, Martti, 'The Advantage of Treaties: International Law in the Enlightenment,' Edinburgh Law Review 13 (2009): 27-67.

Krohg, Christian, Forsøg til en Ledetraad ved Forelsninger over Folke-Retten (Copenhagen: Andreas Seidelin, 1803).

Krug, Wilhelm Traugott, Versuch einer Systematischen Enzyklopädie der Wissenschaften. Zweiter Theil (Jena: J.G. Voigt, 1797).

Leerberg, Nora Naguib, The Legal Politics of Neutrality in the Age of Privateering. Martin Hübner's Law of Neutrality and Prize (Oslo: Dreyer, 2015).

Mably, Gabriel Bonnot de, Le droit public de l'Europe fondé sur les traités conclus jusqu'en l'année 1740, 2 vols. (La Haye: Jean Van-Duren, 1746).

Martens, Georg Friedrich von, Einleitung in das positive Europäische Völkerrecht auf Verträge und Herkommen gegründet (Göttingen: Johann Christian Dieterich, 1796).

Martens, Georg Friedrich von, Recueil des principaux traités d'alliance, de paix, de trêve, de neutralité, de commerce, de limites, d'échange etc. conclus par les puissances de l'Europe, 7 vols. (Goettingue: Dieterich, 1791-1801).

Martens, Georg Friedrich von, Précis du droit des gens moderne de l'Europe fondé sur les traités et l'usage, 2nd and revised ed. (Gottingue: Dieterich, 1801). 
Marzagalli, Silvia and Müller, Leos, "In apparent disagreement with all law of nations in the world": Negotiating neutrality for shipping and trade during the French Revolution and Napoleonic Wars,' The International Journal of Maritime History 28 (2016): 108-117.

Michalsen, Dag, 'Legislators, Journals, and the Public Legal Sphere in Scandinavia around 180o,' in Eighteenth-Century Periodicals as Agents of Change, ed. Ellen Krefting, Aina Nøding and Mona Ringvej (Leiden and Boston: Brill Academic Publishers, 2015), 202-214.

Neff, Stephen C., War and the Law of Nations. A General History (Cambridge: Cambridge University Press, 2005).

Nørregaard, Lauritz, Natur-Rettens første Grunde, 2nd ed. (Copenhagen: Gyldendals Forlag, 1784).

Pitts, Jennifer, 'Empire and Legal Universalisms in the Eighteenth Century,' The American Historical Review 117 (2012): 92-121.

Pocock, J.G.A., Barbarism and Religion IV: Barbarians, Savages and Empires (Cambridge: Cambridge University Press, 2005).

Pourchasse, Pierre, 'Danish shipping in the Mediterranean during the Revolutionary wars (1793-1795),' The International Journal of Maritime History 28 (2016): 165-179.

Pufendorf, Samuel, Two Books of the Elements of Universal Jurisprudence, transl. W.A. Oldfather (Indianapolis, IN: Liberty Fund, 20o9).

Schlegel, J.W.F., Naturrettens eller den almindelige Retslceres Grundscetninger (Copenhagen: Johan Frederik Schulz, 1798).

Schlegel, J.W.F., An examination of the sentence in the case of the Sweedish convoy pronounced in the High Court of Admiralty of England on the eleventh of June, 1799 (London: W. Wilson, 180o).

Stapelbroek, Koen, 'Universal Society, Commerce and the Rights of Neutral Trade,' in Universalism in International Law and Political Philosophy, ed. Petter Korkman and Virpi Mäkinen (Helsinki: Helsinki Collegium for Advanced Studies, 20o8), 63-89.

Stapelbroek, Koen, 'The Rights of Neutral Trade and its Forgotten History,' in Trade and War: The Neutrality of Commerce in the Interstate-System, ed. Koen Stapelbroek (Helsinki: Helsinki Collegium for Advanced Studies 2011), 3-13.

Vattel, Emer de, The Law of Nations, ed. Béla Kapossy and Richard Whatmore (Indianapolis, IN: Liberty Fund, 2008).

Wilson, Eva, Seerup, Jacob and Hammar, Anna Sara, 'The education and careers of naval officers in the long eighteenth century: an international perspective,' Journal for Maritime Research 17 (2015): 17-33.

Zurbuchen, Simone, 'Emer de Vattel on the Society of Nations and the Political System of Europe,' in System, Order, and International Law, eds. Stefan Kadelbach, Thomas Kleinlein and David Roth-Isigkeit (Oxford: Oxford University Press, 2017), 263-282. 